\title{
DISSERTAÇÕES
}

\section{A tragédia de Maria: o assassinato enquanto experiência constitutiva}

Ludmila Gaudad Sardinha Carneiro

Curso: Mestrado em Sociologia

Data da defesa: 25 de novembro de 2008

Orientadora: $\operatorname{Prof}^{\mathrm{a}} \mathrm{Dr}^{\mathrm{a}}$ Lourdes Maria Bandeira

\section{Resumo}

As experiências que compõem a trajetória de vida de um indivíduo são alicerçadas em relações generizadas que o constituem, sobretudo, enquanto mulher ou homem em nossa sociedade. A cada uma destas duas categorias culturalmente construídas, porém muito bem sedimentadas como naturais no imaginário social, são remetidas uma série de características que estruturam o que é normal ou desviante para o comportamento de cada uma delas.

Por meio da história oral de Maria* é possível reconstruir uma trajetória de vida calcada em relações generizadas que a instituíram prioritariamente como mulher e, consequentemente, como mãe. Tida antes como mulher do que como pessoa, Maria* passou por uma série de experiências que só foram possíveis unicamente pelo ser generizado em que ela se tornou. Sendo mulher, prioritariamente, experiências de vitimização. 
O meio encontrado para sair do esperado papel social de vítima foi subverter as características tidas como normais para as mulheres, assumindo um suposto desvio ao aproximar-se do comportamento tido como normal para os homens: agente da violência.

Julgada pelo Sistema Penal não só pelo ato ilícito que cometeu, Maria* respondeu à Justiça e à sociedade não só por tentar cometer assassinato, mas principalmente por não se comportar, conforme a expectativa social, como mulher e mãe.

Palavras-chave: relações generizadas; sistema penal; experiência; história oral. 